\title{
PELATIHAN PEMANFAATAN DIGITAL MARKETING DALAM PENGEMBANGAN PEMASARAN BAGI PELAKU UMKM
}

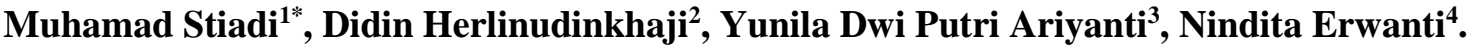 \\ 1,2,3,4 Universitas Ivet Semarang \\ *E-mail: muhamad.stiadi@gmail.com
}

\begin{abstract}
ABSTRAK
Tujuan dilakukanya kegiatan pengabdian kepada masyarakat ini dengan tema pemanfaatan digital marketing dalam pengembangan pemasaran pelaku UMKM di desa sukorejo ini adalah untuk memberikan pengetahuan mengenai digital marketing serta pelatihan penerapan digital marketing. Metode yang di gunakan dalam pelaksanaan kegiatan ini yaitu melalui ceramah dan praktik langsung penerapan digital marketing. Tahapan pelaksanaan acara ini meliputi pembukaan dan pengenalan digital marketing, pemaparan tentang digital marketing, pemaparan tentang beberapa masalah yang sering dihadapi UMKM, pemaparan tentang beberapa istilah asing berkaitan digital marketing kemudian dilanjutkan praktik yang berkaitan dengan digital marketing.
\end{abstract}

Kata kunci: Digital Marketing; UMKM; Desa Sukorejo.

\section{TRAINING THE UTILIZATION OF DIGITAL MARKETING IN MARKETING DEVELOPMENT FOR SMALL AND MEDIUM ENTERPRISES (SMES)}

\begin{abstract}
The purpose of carrying out this community service activity with the theme of using digital marketing in the marketing development of SMEs in the village of Sukorejo is to provide knowledge about digital marketing and training in the application of digital marketing. The method used in the implementation of this activity is through lectures and direct practice of implementing digital marketing. The stages of implementing this event include the opening and introduction of digital marketing, exposure to digital marketing, exposure to some of the problems that are often faced by SMEs, exposure to several foreign terms related to digital marketing then continued with practices related to digital marketing.
\end{abstract}

Keywords: Digital marketing, Small and Medium Enterprises (SMEs), Sukorejo village.

\section{PENDAHULUAN}

Jumlah pengguna internet yang terus meningkat saat ini merupakan sebuah peluang yang harus dimanfaatkan khususnya pelaku UMKM. Hal tersebut diikuti dengan bertambahnya jumlah ecommerce dan marketplace, yang secara langsung membuka peluang yang besar bagi para pelaku UMKM untuk dapan memperluas penjualan produk-produk mereka melalui media digital. UMKM di Indonesia memiliki peran yang sangat penting dalam membantu meningkatkan perekonomian negara dan dapat mengurangi pengangguran. Melihat hal tersebut terdapat peluang yang baik untuk berwirausaha. Para pelaku UMKM dapat memanfaatkan penggunaan cara promosi yang lebih efektif dan efisien untuk mendukung peningkatan volume penjualan produk mereka. Akan tetapi, berdasarkan data yang didapat dari detikcom dimana dari 64,2 juta unit UMKM, hanya $13 \%$ nya yang memanfaatkan teknologi digital dalam mengelola usaha. Selain hal itu saat ini pertumbuhan pengguna smartphone yang terus bertambah dan diiringi dengan meningkatnya ekosistem perdagangan online. Ini merupakan peluang yang sangat besar untuk pelaku UMKM dalam meningkatkan volume penjualan produk mereka.

Pelaku UMKM yang menghasilkan berbagai produk. Produk UMKM tersebut harus terpromosikan efektif kepada konsumen atau pelanggan. Hingga tahun 2021 ini belum banyak pelaku UMKM yang menerapkan digital marketing untuk menjual produk yang dihasilkan. Tentu hal ini 
menjadi sebuah persoalan di dalam perkembangan pemasaran yang modern. Pemasaran dengan cara lama sudah banyak ditinggalkan oleh para pelaku usaha dan beralih menggunakan cara pemasaran yang lebih modern yaitu melalui media digital. Saat ini pelaku UMKM belum banyak menggunakan pemasaran digital sebagai media memasarkan produk mereka. Persoalan ini dapat diatasi dengan melakukan banyak kegiatan berupa pengetahuan untuk memperkenalkan mengenai pentingnya penguasaan digital marketing bagi pelaku usaha. Sehingga dengan terbukanya peluang ini UMKM dapat memanfaatkan untuk mencari konsumen baru dan jangkauan pemasaran yang lebih luas. Persoalan ini juga dimanfaatkan oleh berbagai pihak salah satunya yaitu para reseller yang menjual produk yang lebih tinggi harganya. Hal tersebut tidak terjadi apabila pelaku usaha dapat memasarkan produknya sendiri dengan memanfaatkan teknologi. Melakukan pemasaran dengan media digital seharusnya tidak menjadi kendala bagi pelaku UMKM. Bahkan dengan melihat perkembangan teknologi saat ini, produk- produk UMKM di desa Sukorejo dapat dikirim keseluruh indonesia maupun ke luar negeri. Promosi menggunakan media digital merupakan cara efektif untuk pelaku UMKM mengembangkan usaha mereka dan dapat menjangkau pasar yang lebih luas. Sasaran dari pelatihan ini adalah pelaku UMKM di desa sukorejo kecamatan kesesi kabupaten pekalongan. Pada pelatihan ini bertujuan untuk memberikan pengetahuan pada pelaku UMKM mengenai digital marketing.

Tujuan kegiatan ini adalah untuk memberikan solusi untuk mewujudkan keinginan pelaku UMKM untuk mempromosikan produk mereka di media digital.

Berikut tujuan lebih rinci mengenai kegiatan pengabdian kepada masyarakat berikut ini.

1) Agar pelaku usaha mengenal digital marketing

2) Agar UMKM memahami lebih jauh mengenai digital marketing digital marketing untuk dunia usaha.

3) Agar pelaku usaha mampu menghadapi masalah mengenai pemasaran khususnya pemasaran digital dan mencari solusi efektif dalam memecahkanya

4) Agar UMKM dapat menerapkan digital marketing dalam dunia usaha mereka

5) Agar pelaku usaha mengerti istilah-istilah asing dalam digital marketing.

\section{METODE}

\section{Lokasi Pengabdian}

Lokasi pelaksanaan pengabdian pada masyarakat di desa Sukorejo RT 02 RW 01, kecamatan

Kesesi, kabupaten Pekalongan.

\section{Ruang Lingkup Pengabdian}

Kegiatan pengabdian kepada masyarakat ini dilakukan untuk memberikan pengetahuan mengenai digital marketing pada pelaku UMKM di desa Sukorejo, kecamatan kesesi, kabupaten pekalongan. Kegiatan ini disampaikan dengan metode ceramah dan pelatihan praktik mengenai digital marketing dan penerapanya. Peserta kegiatan ini adalah pelaku UMKM desa Sukorejo.

\section{Kelompok Sasaran}

Kegiatan ini di fokuskkan bagi pelaku UMKM desa Sukorejo

\section{HASIL DAN PEMBAHASAN}

Beberapa tahap yang dilakukan pada pelaksanaan kegiatan pengabdian ini anatara lain:

1) Pembukaan dan pengenalan digital marketing.

2) Pemaparan tentang Digital Marketing

3) Pemaparan tentang beberapa masalah yang sering dihadapi UMKM

4) Pemaparan tentang beberapa istilah asing berkaitan digital marketing

5) Beberapa praktik yang berkaitan dengan digital marketing.

Berdasarkan pengamatan yang telah kita lakukan dari hasil kegiatan pengabdian kepada masyarakat dengan tema pelatihan pemanfaatan digital marketing dalam 
pengembangan pemasaran bagi pelaku UMKM bertempat di desa Sukorejo kecamatan Kesesi kabupaten Pekalongan telah berhasil dilaksanakan pada sabtu 22 April 2021. Indikator yang dapat dicapai dari pelatihan ini dilihat dalam proses pelatihan ini yaitu peserta dapat mengerti materi yang disampaikan dengan jelas, peserta dapat mengikuti pelatihan praktik dengan baik mengenai digital marketing.

Adapun faktor pendukung dalam kegiatan ini yaitu lingkungan tempat kegiatan pengabdian ini yang kondusif, masyarakat sekitar menyambut dengan baik kedatangan tim pelaksana pengabdian dengan baik dan tersedianya peralatan pendukung yang lengkap serta adanya dukungan jaringan yang bagus karena dalam pelaksanaan pelatihan yang di lakukan dengan praktik langsung harus menggunakan gadget yang terhubung dengan internet.

Faktor penghambat dalam kegiatan ini belum di temukan hingga akhir pelaksanaan acara.

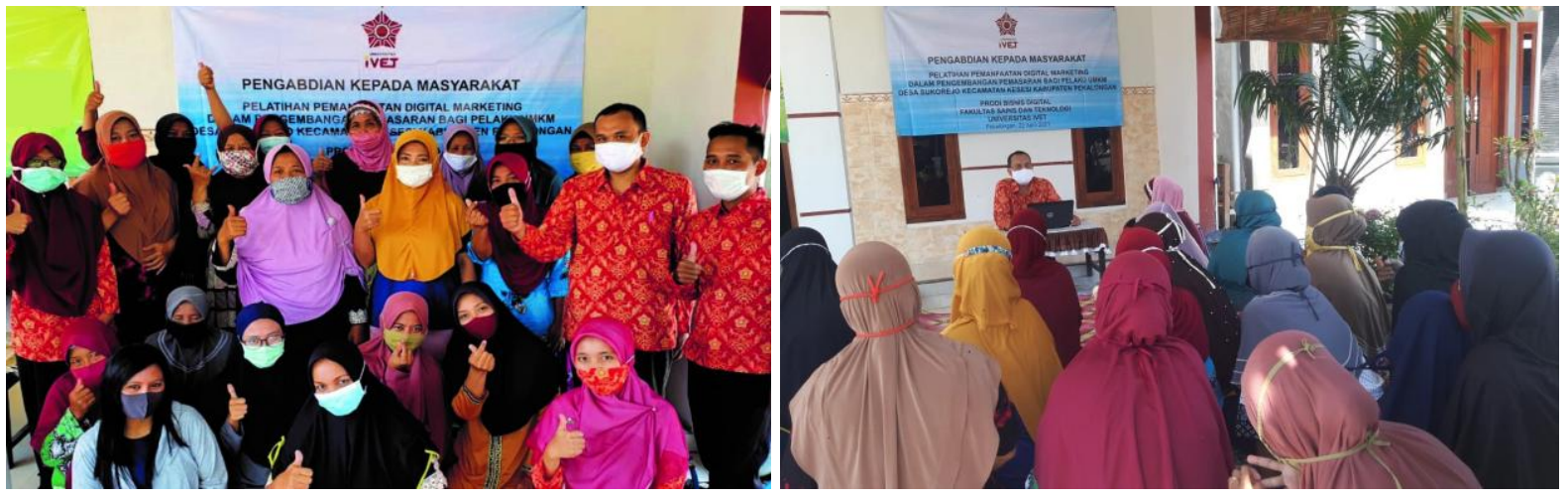

Gambar 1. Pelaksanaan Kegiatan Pengabdian pada Masyarakat

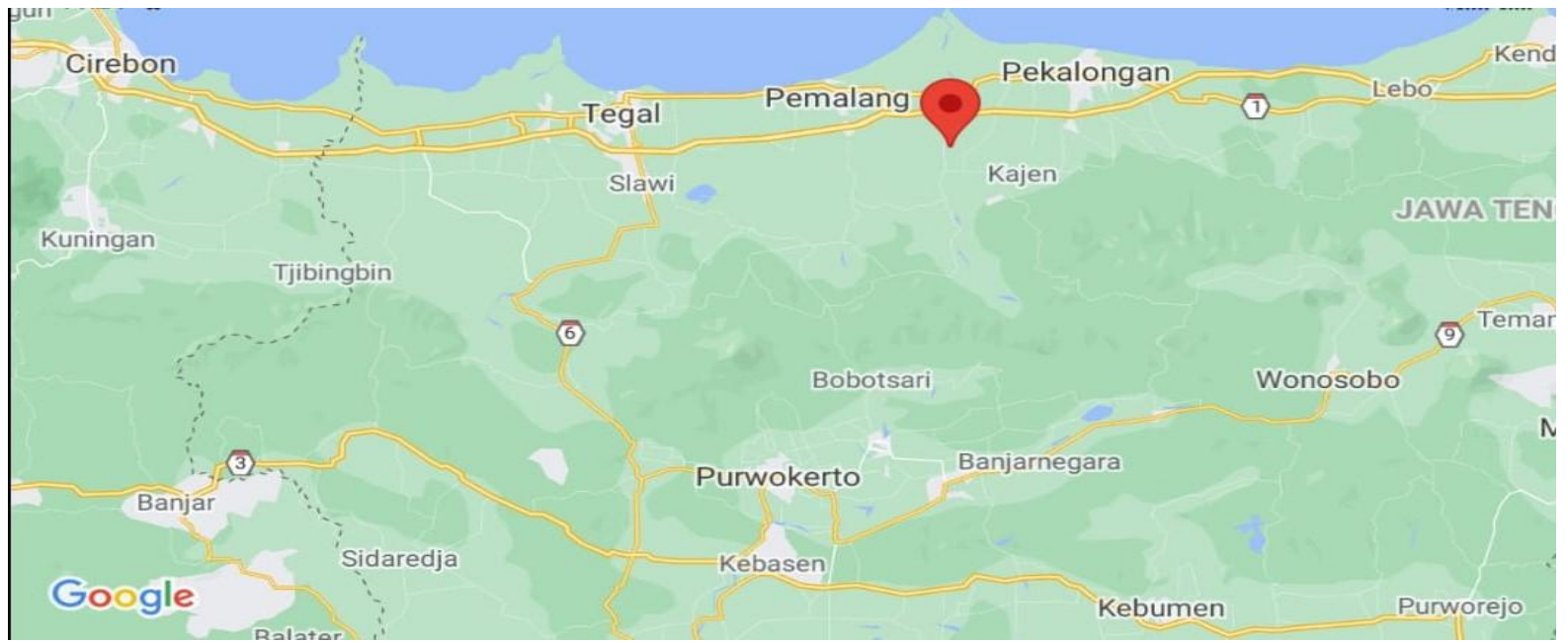

Gambar 2. Lokasi Pelaksanaan Kegiatan Pengabdian pada Masyarakat

\section{SIMPULAN}

Kegiatan pengabdian kepada masyarakat ini dengan tema pelatihan pemanfaatan digital marketing dalam pengembangan pemasaran bagi pelaku UMKM desa Sukorejo bertujuan agar masyarakat khususnya pelaku UMKM di desa Sukorejo ini mengetahui digital marketing dan dapat melakukan penerapanya. Sebelum diadakanya pelatihan digital marketing ini pelaku UMKM masih banyak yang belum mengetahui mengenai digital marketing ini, Sebagian besar mereka juga mengharapkan adanya bantuan modal usaha untuk dapat mengembangkan usaha mereka.

\section{UCAPAN TERIMAKASIH}


Keberhasilan pelaksanaan pengabdian pada masyarakat dan penyusunan laporan ini tidak lepas dari bantuan dan keterlibatan berbagai pihak, oleh karena itu pada kesempatan ini kami mengucapkan terimakasih kepada yang terhormat:

1. Rektor Universitas Ivet Bapak Prof. Dr. Rustono, M. Hum.

2. Dekan Fakultas Sains dan Teknologi Bapak Dr. Fuad Abdillah, S.T., M.T.

3. Ketua LPPM Universitas Ivet Bapak Dr. Slamet, M.Pd., M.Si.

4. Kordinator UMKM dan para peserta pengabdian pada masyarakat.

5. Semua pihak yang telah membantu terlaksananya pengabdian pada masyarakat ini.

Semoga bantuan dan perhatian yang diberikan bermanfaat bagi kita semua.

\section{DAFTAR PUSTAKA}

Egziabher, T. B. G., \& Edwards, S. (2013). Pelatihan E-Commerce Dan Digital Marketing Pada Umkm Kota Sawahlunto Ketua. Africa's Potential for the Ecological Intensification of Agriculture, 53(9), 1689-1699.

Farell, G., Thamrin, T., \& Novid, I. (2019). Pelatihan Pemanfaatan Digital Marketing Dalam Pengembangan Pemasaran Dan Kewirausahaan UKM Pada Kota Sawahlunto. Suluah Bendang: Jurnal Ilmiah Pengabdian Kepada Masyarakat, 19(1), 42. https://doi.org/10.24036/sb.0310

Ilham, M., Baladraf, F., Sembodo, G., \& Ulfah, L. (2018). Pelatihan Sukses Berbisnis Online Memajukan Perekonomian Masyarakat Melalui Pemasaran Online Putat Jaya Surabaya. Jurnal Abdikarya, 01(1).

Rakib, M., Syam, A., Marhawati, \& Dewantara, H. (2020). Pelatihan Merancang Bisnis Online di Masa Pandemi bagi Mahasiswa. Jurnal Dedikasi, 22(2), 129-134.

Subandi. (2020). Pelatihan Pemasaran Ekspor Melalui Internet Bagi Oleh : J-Abdimas.

Syahniar, T. M. (2018). Laporan Akhir Pengabdian Masyarakat. 6 (November), 1-15. 